\title{
Road to ruin
}

\author{
Tough laws won't save poor nations' ecosystems until the impacts \\ of developments are taken seriously
}

\author{
William Laurance
}

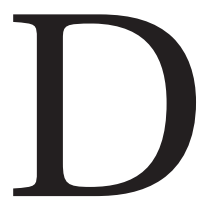

ozens of Indonesians killed by landslides this spring have paid the price of unchecked development. Many other innocents in developing nations die each year as rampant illegal logging and deforestation denude steep hillsides, loosening soil and allowing heavy rains to create deadly deluges.

Such environmental perils are increasingly common across much of the world as native forests are fragmented, waterways polluted, and oceans over-harvested. The onslaught is especially alarming in the tropics, where an area of forest the size of 40 football fields is destroyed every minute. Thousands - perhaps millions - of species are at risk.

Yet remarkably, many developing nations have good laws to regulate development and protect their natural ecosystems. Indonesia, Brazil, Bolivia and the Democratic Republic of the Congo, for example, all have strong forestry codes and environmental laws. So why aren't they working?

A key problem is that environmental impact assessments (EIAs), required by law for most development projects, are often utterly inadequate. Nowhere is this clearer than in Brazilian Amazonia, which is yielding to the biggest expansion in paved highways in its history. By greatly increasing access to the heart of the Amazon, these highways are opening a Pandora's box of threats such as illegal logging, hunting, mining and land colonisation. But the EIAs for these new highways only evaluated the direct effects on the narrow strip of land being cleared for each road. None of the alarming indirect impacts that commonly follow highway construction were covered.

A similarly narrow evaluation is under way for the planned expansion of the Panama Canal, which will allow supertankers to travel the waterway. As less than 700 hectares of rainforest will be destroyed, everyone expects the project will get the green light. Yet this $\$ 5.2$ billion scheme will have a profound impact on a nation as small as Panama. Increased land speculation, overheated development and growing demand for construction timber will put pressure on forests across the country. Even cursory consideration of the project's indirect effects reveals these issues.

In addition, many EIAs are laughably superficial. For example, a biological survey for a planned housing complex in Panama's suburban forests identified only 12 common bird species. A 2-hour census of the same area by experienced birdwatchers tallied 121, including several rare and threatened species. The project was approved despite scientists' warnings to the authorities of flaws in the study.

Why are EIAs often so poor? Firstly, they are usually paid for by the project backer, who pushes to ensure approval with minimum costs. In such a system, environmental firms that get projects accepted with few mitigation measures are in high demand, while those with a rigorous reputation are avoided.

Secondly, government agencies that evaluate EIAs often fail to apply their own environmental rules. The process is also vulnerable to corruption, since government employees are often poorly paid while project backers have deep pockets and a large financial stake to protect. Even EIAs with glaring faults are sometimes approved.

Finally, it is rare for a project to be halted on environmental grounds because the burden of proof falls on those who oppose it, not those who favour it. A planned highway might sever a critical forest corridor, or open up a pristine valley to exploitation, but unless it can be shown that it would irreparably harm an endangered species or rare ecosystem, the road may be approved regardless. Fighting development projects takes considerable time, money and expertise, and this stacks the deck heavily against citizens and publicinterest groups who often oppose risky developments.

What can be done to improve the situation? Increasing public awareness should help focus attention on the EIA process and its many weaknesses - including a dire need to evaluate both the direct and indirect impacts of major projects. Equally important is greater involvement by society and by environmental groups. Government agencies that approve or halt projects are often responsive to external pressure, and they rely on lobbying by conservationists to help balance development forces. If you want to help the global environment, supporting an active environmental group in a developing nation may be a key strategy.

Of course, serious flaws in EIAs are not confined to developing countries. The drafter of the US Environmental Protection Act, Lynton Caldwell, has often bemoaned the failure of EIAs to balance the needs of nature against human activities. But in developing nations, conservation interests are often less established, and pressures for exploitation are stronger and more immediate. Better environmental decision-making is crucial if we are to limit these growing threats to the natural world.

Reprinted with permission from New Scientist, issue 2607, 06 June 2007, page 25

William Laurance is a biologist at the Smithsonian Tropical Research Institute in Panama. His latest book is "Emerging Threats to Tropical Forests" (with Carlos Peres, University of Chicago Press, 2006). 